\title{
SELECTED INNOVATION TOOLS IN DESIGNING PROCESS MANAGEMENT ${ }^{3}$
}

\begin{abstract}
This contribution deals with the specification of the current immunity of strategy and status and level of procedural management in special organizational structures referred to as industrial clusters. It represents selected specifics of the design and application of innovative tools, system integration, and agile project management of clusters. It describes and explains the context between the strategy, the organizational structure, and the need for project procedural management at the current position and competitiveness of clusters on the market in demanding energy and environmental conditions. In the end, it shall submit its own author's design scheme for a new organizational project aimed at a cluster structure and draft management process and coordination of clustered projects for their clients.
\end{abstract}

KEYWORDS: Innovation tools, cluster structure, procedural management, project management, system integration.

\section{INTRODUCTION}

According to the nesting theory of M. E. Porter, clusters are an organizational form and a tool of geographical concentration of interconnected companies, institutions, specialized suppliers, and service providers as well as partners in order to prioritize mutual cooperation over sophisticated competition (Kotler \& Keller, 2013). Characteristic of such a situation is that the projects have a shorter implementation time of 3 months to 1 year; reasonable financial volumes and costs for the project with lump sums; a small number of universally skilled people in teams; precise and specific work plan and timetables; cluster managers are often also project managers and project teams work in daily contact; the processing of project tasks and tasks usually takes place individually and manually; communication channels are shorter, decision-making is fast, team members get to know each other sooner, and in more detail, motivational factors are more flexible and targeted estimates and studies (ideas) of projects, which are the basis for planning, are much more accurate and simpler, as it is possible to better know specific conditions and the overall history and needs of the

1 Tomáš Novotný, MSc, PhD, MBA, Národný energetický klaster NEK, Záhradnícka 72, 82108 Bratislava, Slovak Republic; e-mail: info@nek.sk

2 Simona Novotná, MSc, Národný energetický klaster NEK, Záhradnícka 72, 82108 Bratislava, Slovak Republic e-mail: simona.novotna@tuke.sk (corresponding author). ORCID: 0000-00022949-6447.

3 This research was funded by "Koncipovanie a rozvoj integrovanej inovačnej infraštruktúry a vedomostnej bázy $\mathrm{v}$ európskom priestore klastrovej organizácie" under grant number NFP313020ANX5. 
customer and which project (Magretta \& Stone, 2013). Objective and content of the contribution (Fotr \& Souček, 2011):

a) Specification of the current understanding of the strategy and the state and level of process management in cluster structures.

b) Design and application of selected innovative tools and system integration in cluster management.

c) Peculiarities of project process management and definition of conceptual apparatus.

d) Examining the relationship between strategy, organizational structure, and the need for project process management for the competitiveness and innovation of clusters.

e) Own author's scheme of design of a new organizational, project-oriented cluster structure.

f) Design of the process of management and coordination of projects implemented by clusters for clients.

\section{ORGANIZATIONAL STRUCTURE AND PROJECT MANAGEMENT PROCESS MANAGEMENT}

However, this advantage and relative simplicity is also a possible source of some problems (Karabáč et al., 2020) that can arise in the process management/project management of the cluster, namely: conflicts of interest and priorities for project managers and the team leader, as well as the lack of affordable specialists and alternative alternatives in the project; even if the specialist is deployed, the scope of the project will not allow him to fully deploy; it is often partially redundant, time-consuming and costly and inefficient; greater sensitivity of the cluster and project team members to conflicts and risks, or disagreements in the professional approach to the content of projects and at the same time paradoxical informal relationships can be an obstacle in the work discipline; possible delays or shortcomings in any of the managed projects may have a negative impact on other projects (consistency, coherence, etc.) (Hromková \& Holočiová, 2005).

The author of this article perceives clusters as a modern and successful tool for innovation and strengthening the competitiveness of Slovakia, and for a long time, he has been dealing with the subject of the paper in the context of extensive research and publishing activities.

Basis and knowledge of criteria:

a) Industrial production and construction, energy, and environmental problems are long-term socially, industrially, and existentially crucial, and their coexistence affects new innovative solutions for cluster organizations.

b) Innovations change the structures of clusters and companies - the consequence of interventions, personnel changes, and changing needs and expectations of clients in the market.

c) Project process management of activities in organizations is the main activity of management.

d) Management processes and especially production have a key position among the components of the management model.

Project process management is a special and specific way of management, the essence of which is the planning, organization, and management of activities and their resources within the solution of a specific investment, business, product, or construction project for a particular client in order to achieve maximum effect. A process is commonly understood 
as a process (e.g., a technological process, litigation, a financial process). By this procedure, the authors understand a series of consecutive activities, where each sub-activity (elements of this series) is organized mainly functionally (Svozilová, 2011). Every organization that has implemented process management must continuously improve the individual processes and evaluate their efficiency and effectiveness. If we want to improve the process, we must keep it under control, so that it must first be planned, then implemented, and finally monitored. The process, which is not continuously improved, deteriorates, and its effectiveness decreases as the competition develops (Fotr \& Souček, 2011). Process management - can be understood as a management approach focused on monitoring existing processes, their analysis, possible changes, stabilization, or further improvement (Novotný, 2017). Processes, especially management processes and also production processes, play a key role among the components of the management model. For clusters to work, they must therefore define and manage many interconnected processes. The organization and management of processes depend on how efficiently the activities leading from the acquisition of orders to their satisfaction are carried out, how complicated or logically the auxiliary operations are performed to the main processes. Table 1 defines the types of integration and the interests and principles of implementing process management in cluster structures as follows:

Table 1. Integration and implementation of process management

\begin{tabular}{|c|c|}
\hline $\begin{array}{c}\text { THE TYPES OF INTEGRATION AND } \\
\text { INTEREST IN THE PROCEDURE } \\
\text { APPROACH ARE IN: }\end{array}$ & $\begin{array}{c}\text { THE MAIN PRINCIPLES FOR THE } \\
\text { INTRODUCTION OF PROCESS } \\
\text { MANAGEMENT CAN BE } \\
\text { DETERMINED AS: }\end{array}$ \\
\hline $\begin{array}{c}\text { Operations integration - the basis for team } \\
\text { management. At present, a more well - educated } \\
\text { worker is gaining more attention than a one - } \\
\text { sided, low-educated worker. }\end{array}$ & $\begin{array}{c}\text { Starting a new organizational cluster culture } \\
\text { - to teach the whole team and management } \\
\text { to think process. The process begins with } \\
\text { training and teaching. }\end{array}$ \\
\hline $\begin{array}{c}\text { Integration of customers into the cluster } \\
\text { production process. The customer can comment } \\
\text { on how he wants to have the product or service } \\
\text { configured and only then gives the signal for } \\
\text { production. }\end{array}$ & $\begin{array}{c}\text { Reassessment of the internal management } \\
\text { system - elaboration of a new cluster } \\
\text { strategy and the subsequent new creation of } \\
\text { a new organizational structure }\end{array}$ \\
\hline $\begin{array}{c}\text { Supplier integration into the production process. } \\
\text { The supplier becomes a direct part of production } \\
\text { and services and is not just a supplier of } \\
\text { individual components. }\end{array}$ & $\begin{array}{c}\text { Redesign of management processes - } \\
\text { elimination of unnecessary and duplicate } \\
\text { activities; complementing missing activities } \\
\text { and innovating inefficient activities }\end{array}$ \\
\hline
\end{tabular}

Source: authors' work.

Project process management: It is a special and specific way of process management, the essence of which is the planning, organization, and management of activities and their resources within a comprehensive project while respecting time, resource, and cost constraints, in order to achieve the maximum economic effect. It differs from the line or staff management style mainly in temporality, dynamism, and allocation of resources for its implementation (Svozilová, 2011, Veber, 2014). The goal of project management is then to ensure the planning and implementation of a specific successful project in the cluster, which means the case when the project goals were achieved in the planned time and with 


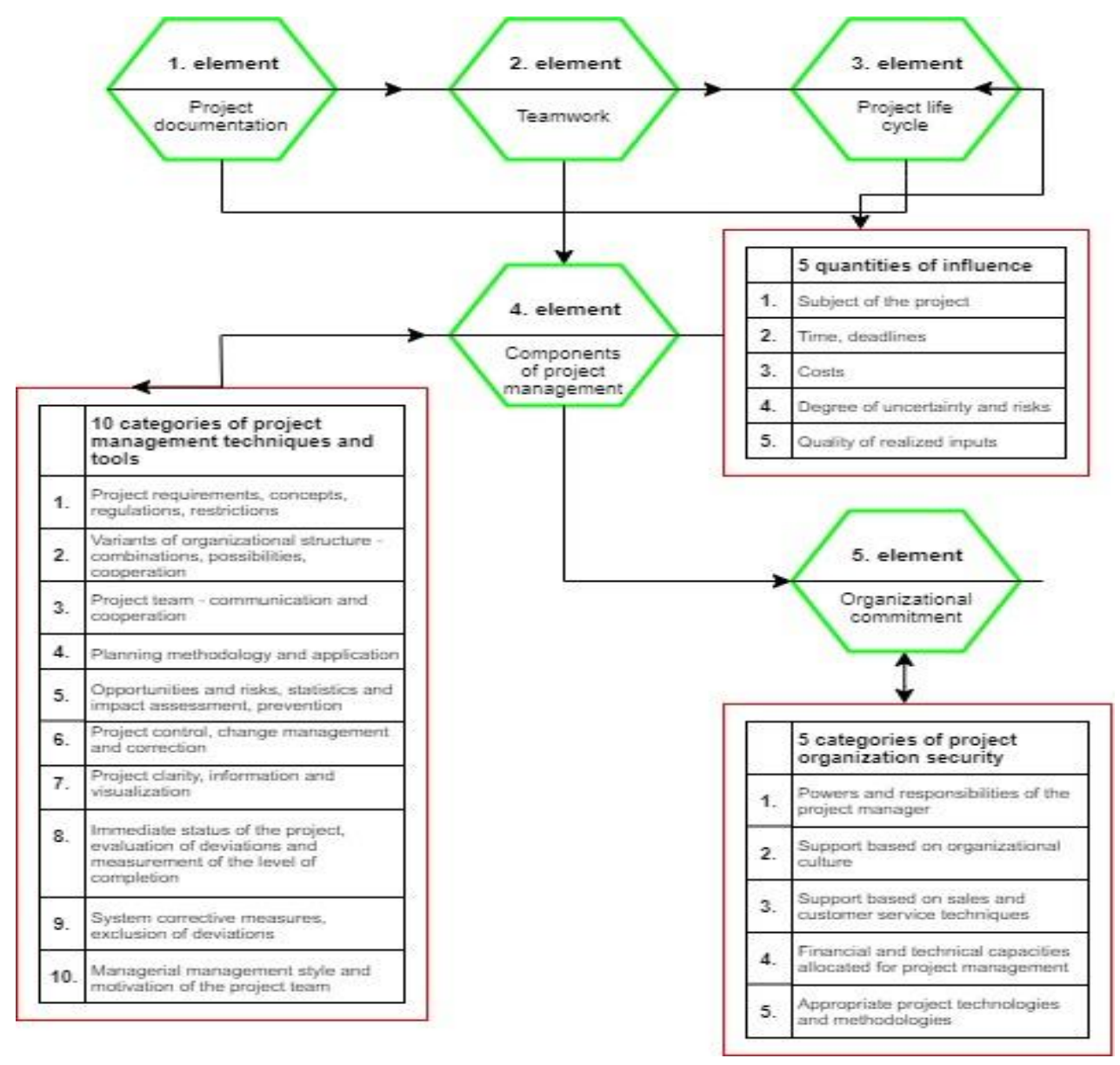

Figure 1. Basic elements of cluster project management

Source: (Plamínek, 2018; authors).

the planned costs. Project management is based on the knowledge that once the scope, complexity, riskiness of the project exceeds a certain level, it is necessary to use adequate methods to manage the entire project (Koporová, 2020, Svozilová, 2011). The main element of any project and management is the project itself (Plamínek, 2018). It is a unique sequence of activities and tasks, which has: a given specific goal to be fulfilled after its implementation; defined schedule and deadlines; the established framework for drawing funds and the regime of pre-financing of the project subject itself (construction of the work, implementation or installation of technology, investment procedures, etc.). From this finding, we can realistically deduce that the project is actually a temporary effort made to create and implement a unique engineering - technical product or service with a defined result, exclusively for the customer. Then the product (result/output) of the project is the goal, result, or other material determinants that are to be created by the project implementation. New professional demands on the team and managerial workforce and 
growing expectations mean that clusters have to consider changing the conventional way of thinking and move to more efficient ways of process management. However, unless the necessity of the change is determined, it is not possible to determine the purpose and method of making the change. According to Figure 1, the basic elements of the project process management itself can be decomposed as follows.

Such questions need to be asked before any attempt to change and design a new process management based on the knowledge and analysis of the authors' research to date, based on theory (Magretta \& Stone, 2013; Veber, 2014), applying the ten general principles of successful change management. According to these principles, one of the most effective changes seems to be the fundamental management of internal cluster management processes (Table 2). The transition to new management methods is also made possible by new innovative approaches and new information technologies, which are part of the management information system and the subject of a separate, relatively extensive policy to support cluster management in the future (Novák, 2017). At the same time, this development should focus on quality and improvement (innovation and new approaches) in cluster projects and products.

Table 2. Ten valid principles of successful change management

\begin{tabular}{|c|c|}
\hline LE 1 & Top management plays a key role in managing change. \\
\hline PRINCIPLE 2 & Developing a vision that must be clearly articulated and understandable to all. \\
\hline PRINCIPLE 3 & $\begin{array}{l}\text { Awareness of the need for change (it must be clear to everyone that change is } \\
\text { a condition for success, even if everything works). }\end{array}$ \\
\hline PRII & $\begin{array}{l}\text { Elaboration of a specific project, which will be used to proceed with the } \\
\text { change of the cluster organization. }\end{array}$ \\
\hline $\mathbf{E} 5$ & Necessity of continuous education with all employees of the organization. \\
\hline PRINCIPLE 6 & Team approach (changes are not made by individuals, but by project teams). \\
\hline PRINCIPLE 7 & Elaboration of a project of gradual implementation of change. \\
\hline PRIN & $\begin{array}{r}\text { Monitoring, evaluation and correction of } \\
\text { identified can b }\end{array}$ \\
\hline PRINCIPLE 9 & $\begin{array}{l}\text { There must be open, ongoing communication between management and other } \\
\text { employees. }\end{array}$ \\
\hline PRINCI & $\begin{array}{l}\text { It is advantageous to cooperate with external consultants as partners in the } \\
\text { implementation of the change. }\end{array}$ \\
\hline
\end{tabular}

Source: authors' work.

\section{DESIGN OF PROJECT PROCEDURAL MANAGEMENT INSTRUMENTS OF INDUSTRIAL CLUSTERS}

The processes themselves are provided by the cluster administration (which means monitoring costs and managing effective sales techniques, technical preparation, and care for resources and assets) and at the same time it is a service staff component for the cluster production and service system (Novotný et al., 2020) for project teams, but mainly for customers - which covers marketing and sales, management and service activities and corporate image. In the hierarchy of process project management, the overall logistics of operation is superior to production - procurement of inputs to projects and products, innovation and development of solutions for the market, as well as planning and distribution 
routes in the cluster's customer portfolio. The culmination of such an organizational structure is the strategy itself with its goals, vision, and tasks in the creation and implementation of projects, which is provided by project management and affects the overall organizational culture, presentation, and image of the cluster and its ethical and social background and position. If the specifications of the main competencies of the cluster organization are already determined, all the necessary links and system elements arise for setting up a clear and simple design of the project management and coordination process in the cluster, which evokes the design scheme of the new organizational structure 2.

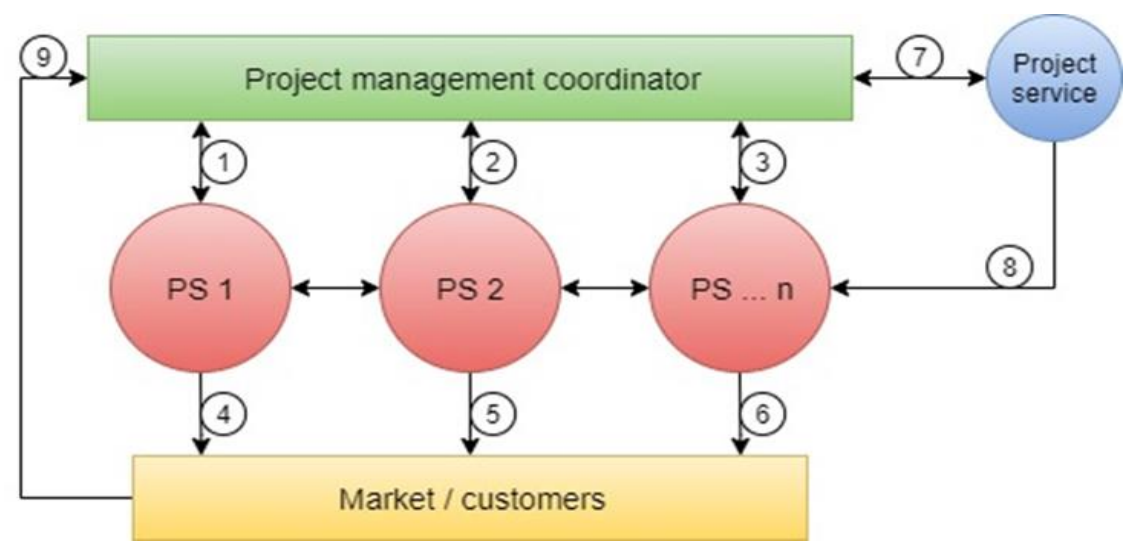

Figure 2. Scheme of design of a new organizational structure of a cluster organization Source: authors' work.

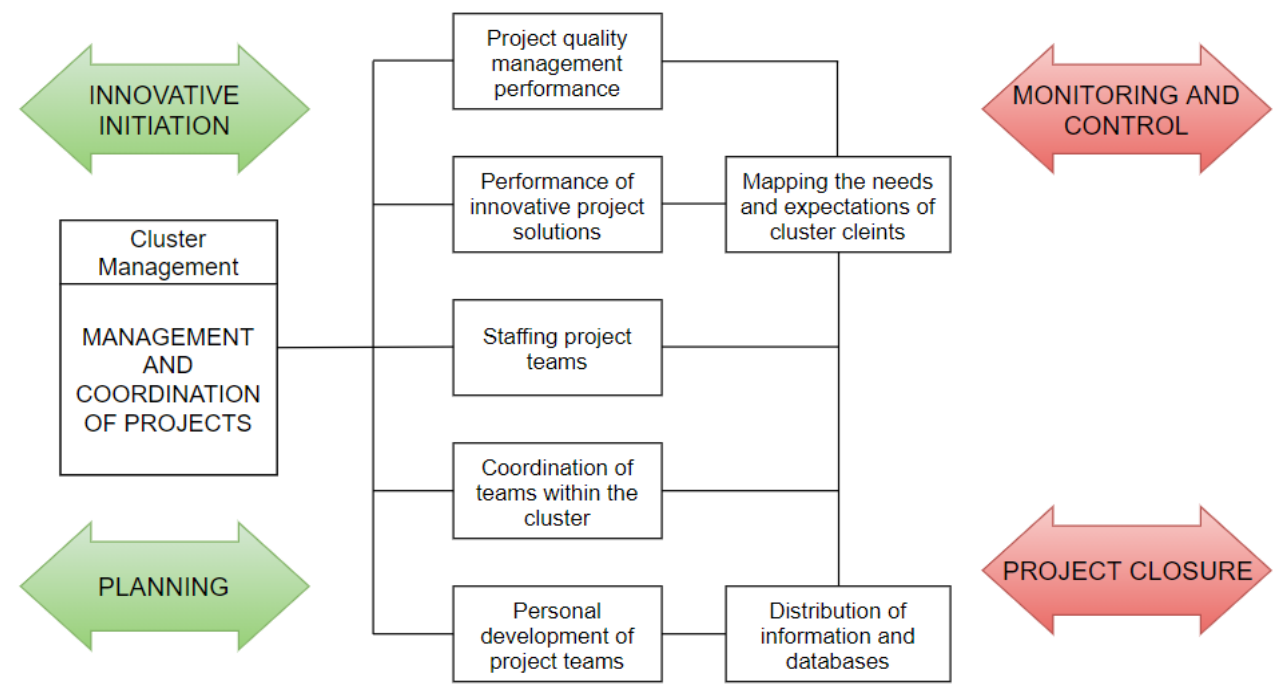

Figure 3. Project management process design and coordination in clusters

Source: (Novotný, 2017; authors). 
The principle consists in the abolition of the structure based on staff functions with a fixed content and competencies and the creation of a relatively free organizational structure with the decisive position of individual project/executive groups PS 1, PS 2, to PS ... n, which freely and relatively independently provides crucial cluster activities. (Projects, orders, consulting, processes, etc.) and their cooperation and coordination is ensured by the management in the position of universal coordinator. A part of this organizational system is also a separate team, understood as a project service, providing economic, legal, administrative and other security and service activities at the same time for all PS. The author's design of the diagram of the process of innovative project management and coordination for the needs of the solved cluster organization can be seen in these contexts and system elements (Figure 3).

The proposal sufficiently responsibly [9], unambiguously, and exhaustively describes the supporting elements and links between them in the conditions of two-stage project management and engineering activities in clusters for customers and is the authors' application with modifications of the already verified solution. At the same time, it is appropriate to emphasize the fact that the result of project process management as a combination of invention and forces is and will always be the commitment of the cluster organization to research, technological development, production, and innovation for industrial investment and commercial use by its member firms.

\section{CONCLUSION}

The paper briefly and clearly describes the current state of process management of clusters in connection with their innovative possibilities and proposes 10 essential value principles for assessing the state of clusters, the scheme of the new organizational structure and the project management process, and their coordination in cluster organizations. Management of projects specializing in industry, construction, manufacturing, and especially energy and ecology in large and international companies and holdings is a common phenomenon, but in cluster groups and their companies (members) that deal with the project, the most common differences are the so-called. "Mega - enterprises" in one-off creative activity (in the case of a project designed for their own needs) or in short-term, recurring, or overlapping activities (in the case of management service for customer projects). Therefore, the study and design of models, manuals, and tools to support project process management is becoming an important area of research and support for the competitiveness of industrial cluster organizations in the future and needs to be addressed and addressed extensively.

\section{REFERENCES}

Fotr, J., Souček, I. (2011). Investiční rozhodování a řizení projektů. Grada Publishing.

Hromková, L., Holočiová, Z. (2005). Teorie průmyslových podnikatelských systémů I. Univerzita Tomáše Bati ve Zlíně.

Karabáč, Š., Koporová, K., Novotná, S. (2020). Spoločná expertná báza pre technologické mapy a inovačné stratégie $v$ priemyselných klastrových habitatoch. Komplexná záverečná výskumná správa. NEK.

Koporová, K. (2020). Inovačné faktory tvorby, poslania, premis a klúčových zmien v sektore stavebnictva do roku 2030 [Paper presentation]. [In:] ECO\&ENERGY Innovation, Košice, Slovakia, MH SR+NEK. 
Kotler, P., Keller, L. K. (2013). Marketing management, analýza, plánovani,využití, kontrola. Grada publishing.

Magretta, J., Stone, N. (2013). Co je management. Management Press.

Novák, A. (2017). Inovace je rozhodnutí, Kompletní návod jak dělat inovace nejen v byznysu. Grada Publishing.

Novotný, T. (2017). ENERGOFUTURA Stratégia a budúcnost' energetického a environmentálneho prostredia. MH SR.

Novotný, T., Hrabovský, G., Marcin, J. (2020). Koncipovanie inovačných nástrojov energetických a environmentálnych klastrových habitatov. MH SR and NEK.

Plamínek, J. (2018). Vedení lidí, týmu a firem. Praktický atlas managementu. Grada Publishing.

Svozilová, A. (2011) Projektový management. Systémový př̀stup k ř́zení projektů. Grada Publishing.

Veber, J. (2014). Management, Základy, moderní manažerské př́stupy, výkonnost a prosperita. Management Press.

DOI: $10.7862 / \mathrm{rz} .2021 . \mathrm{mmr} .25$

The text was submitted to the editorial office: December 2021.

The text was accepted for publication: December 2021. 